\title{
Net present value (NPV) of the rehabilitated irrigation channels to increase agricultural production
}

\author{
Is kandar Pani ${ }^{1}$, Dinar Dwi Anuge rah Putranto ${ }^{2 *}$ and Putri Kus uma Wardhani ${ }^{3}$ \\ Post Graduate Program of Civil Engineering and Planning, Faculty of Engineering, Sriwijaya University ${ }^{1}$ \\ Civil Engineering and Planning, Faculty of Engineering, Sriwijaya University, Jl. Srijaya Negara, Bukit Besar, \\ Palembang, Indonesia ${ }^{2}$ \\ Civil Engineering and Planning, Faculty of Engineering, Sriwijaya University, Jl. Raya Inderalaya Km.32 Inderalaya, \\ Ogan Ilir District, South Sumatra, Indonesia ${ }^{3}$
}

Received: 26-February-2021; Revised: 09-May-2021; Accepted: 11-May-2021

(C)2021 Iskandar Pani et al. This is an open access article distributed under the Creative Commons Attribution (CC BY) License, which permits unrestricted use, distribution, and reproduction in any medium, provided the original work is properly cited.

\begin{abstract}
The Indonesian government created the Technical Guidelines for the Acceleration of Water Use Improvement (P3-TGAI) to enhance the economy of several communities and to support food self-sufficiency. This research was, therefore, conducted to analyze the performance improvement of the irrigation network management program at P3-TGAI. This involved evaluating the increase in irrigated rice fields due to the rise in the quality and quantity of irrigation canal construction and determining the level of satisfaction of the P3-TGAI beneficiaries using Spearman rank correlation analysis. The results showed that the irrigation channels rehabilitated with brick construction increased irrigation water discharge from $19.25 \mathrm{l} / \mathrm{sec}$ to $40.25 \mathrm{l} / \mathrm{sec}$ and this further increased the area of irrigated rice fields by 25.2 hectares. This was observed to be due to the increment in the length of the channel from $446.2 \mathrm{~m}$ to $507 \mathrm{~m}$. Moreover, canals rehabilitated with light concrete construction increased the flow of irrigation water from $18.50 \mathrm{l} / \mathrm{sec}$ to $27.75 \mathrm{l} / \mathrm{sec}$ and this caused the area of irrigated rice fields to increase by $11.1 \mathrm{Ha}$. This was discovered to be due to the increment of the channel length to $1,220 \mathrm{~m}$. Furthermore, the Benefit-Cost Ratio $(B / C)$ ratio of the concrete lining construction was recorded to be 6.79> 0 while the brick construction had 14.53>0. Therefore, the canal rehabilitated using concrete lining construction is considered better. The level of correlation between P3-TGAI farmer participation was found to be $0.841 * *$. It was also discovered that the satisfaction level of farmer groups with concrete construction was $0.815 * \%$ while those with brick construction was $0.864 *$. This means the farmers prefer a better-quality level of irrigation network than adding more length to the canals as indicated with a confidence level of $0.932 * *$ and a significance level of 0.01 . The findings showed the farmers are delighted with the P3-TGAI program conducted independently with the assistance of government funds.
\end{abstract}

Keywords

Water discharge, Tertiary irrigation channels, Channel construction, B/C.

\section{Introduction}

Sustainable agriculture is required to meet the needs of the present and future generations while ensuring the provision of benefits, environmental sustainability as well as social and economic justice. The Food and Agriculture Organization (FAO) is promoting Sufficiency Food and Agriculture (SFA) to help countries worldwide achieve zero hunger and Sustainable Development Goals (SDGs). This is considered necessary due to the projection of a global food crisis [1].

\footnotetext{
*Author for correspondence
}

On this basis, Indonesia is also preparing 370,000 hectares of agricultural land in Kalimantan and 230,000 hectares in South Sumatra to reduce the one million hectares program stalled [2].

Moreover, the increase in agricultural production also needs to be accompanied by the improvement of community participation in the maintenance of irrigation networks. This is important due to the ability of smooth water supply through irrigation channels and the more expansive drained agricultural area to increase agricultural production. Institute for Global Environmental Strategies (IGES) records showed the water supply to farm fields in South Asia is dominated by land irrigation systems with low efficiency and this method is applied to $97 \%$ of the total agricultural land 
because it is the cheapest [3]. The authority to build and maintain irrigation network systems in Indonesia is regulated by the Minister of Public Works and Housing of the Republic of Indonesia, No.14 / PRT / M / 2015 [4]. Meanwhile, the development and management of tertiary irrigation systems are the responsibility of the farmers' association as indicated in the Water User Farmers Association (P3A). Recent reports, however, showed an average of $30 \%$ and up to $60 \%$ of the primary and secondary irrigation channels are damaged [5].

Most of the damages recorded in the tertiary network damage are due to landslides and the accumulation of sediments and this is expected to continue due to lack of regular maintenance. This has further led to a decrease in the quality of water services in the tertiary channel function [5]. Moreover, the decline in the quality of the canal function was discovered to be due to the loss of water during distribution as well as lowquality construction by farmers. The Ministry of Public Works and Housing (PUPR), therefore, implemented the program for the Acceleration of Water Use Improvement (P3-TGAI) program to support the food sovereignty programand other efforts to increase the economic capacity and welfare of the community. This programinvolves the construction of irrigation networks in a participatory manner [6]. This involves the planning, implementation, supervision, and management of the networks with the community. Social assistance funds are channeled directly to groups of farmers operating as legal entities such as P3A, Association of Water User Farmers Association (GP3A), and Parent Association of Farmers Using Water (IP3A) with legal regional or village heads. This farmer association is the beneficiary group and abbreviated as Beneficiary Group (KPM) and the canal rehabilitation activities were conducted through proposals compiled by this group through a village deliberation process. The farmer groups were empowered to strengthen and increase the independence of farming communities. Several problems related to the quality and quantity of tertiary irrigation channels have been identified in implementing the $\mathrm{P} 3 \mathrm{~A}$. The most recurring two is sues is the repair of channels using brick construction by some KPM while others used lining concrete, thereby, producing different results. Another problem is the volume of the flow rate. Therefore, this study analyzed the Benefit-Cost Ratio $(\mathrm{B} / \mathrm{C})$ value related to the quality and quantity of irrigation canals rehabilitated by the community through the P3-TGAI program in improving irrigation performance.

\section{Methodology}

\subsection{Research sites}

The Komering irrigation area is one of the irrigation systems built in the province of South Sumatra, Indonesia is using Komering river discharge through the construction of the Perjaya dam. The Karangsari right sub-tertiary system (SS. right KS) in Karangsari village, Belitang III district, and the sub-tertiary channel which is the secondary right Bedilan (SS. right Bedilan) in Bedilan village, Belitang district is part of those that benefit from the P3-TGAI program. This area is geographically located on latitude $04^{\circ} 05^{\prime}$ 11,04 "-04 06 ' 30,96" Southern Hemisphere and longitude $104^{\circ} \quad 39^{\prime} \quad 35,28^{\prime}-104^{\circ} \quad 41$ ' 12,12 ' east longitude in East Ogan Komering Ulu Districts, of South Sumatra province, Indonesia as indicated in Figure 1.

\subsection{Data collection and analysis}

The steps used in collecting and analyzing data to assess the performance improvement of irrigation network management in the P3-TGAI program are as indicated in the following Figure 2.

2.2.1 Acquisition of data

Flow rate measurement

Flow velocity was measured at several tertiary channels using a current meter for irrigation canal depths $<1 \mathrm{~m}$ with the height observed to be sufficient at one point at $0.6 \mathrm{~h}$ where $\mathrm{h}$ is water depth and $0.6 \mathrm{~h}$ was measured from the surface water as shown in Equation 1.

$V=V_{0,6} \mathrm{~m} / \mathrm{det}$

Where,

$\mathrm{V}_{0.6}=$ Flow velocity value with current meter at a depth of $0.6 \mathrm{~h}$.

The amount of discharge was calculated using the following Equations.

$Q=V \times A$

$A=b h+t h^{2}$

$T=b+2 t y$

The parameters for the trapezoidal section are presented in Figure 3 while the flow rate was computed using Equation 2. The $t$ is the side slope of the channel cross-section, $A$ is the cross-section area, $\mathrm{b}$ is the bed width, and $y$ is the water depth. $\mathrm{Q}$ is the discharge. $\mathrm{T}$ is top cross-sectional width. 


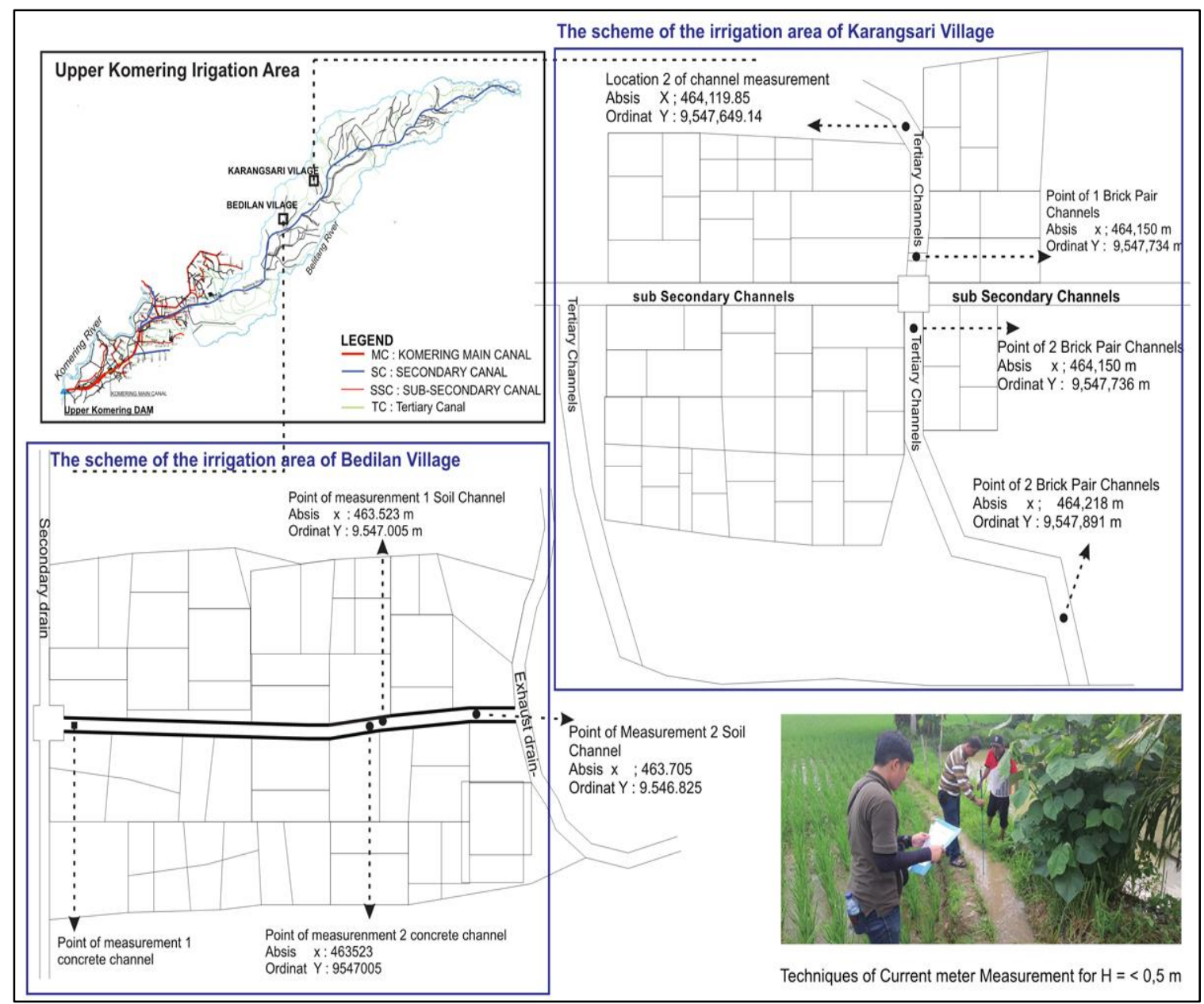

Figure 1 Research locations and measuring of flow rate points in the irrigation networks

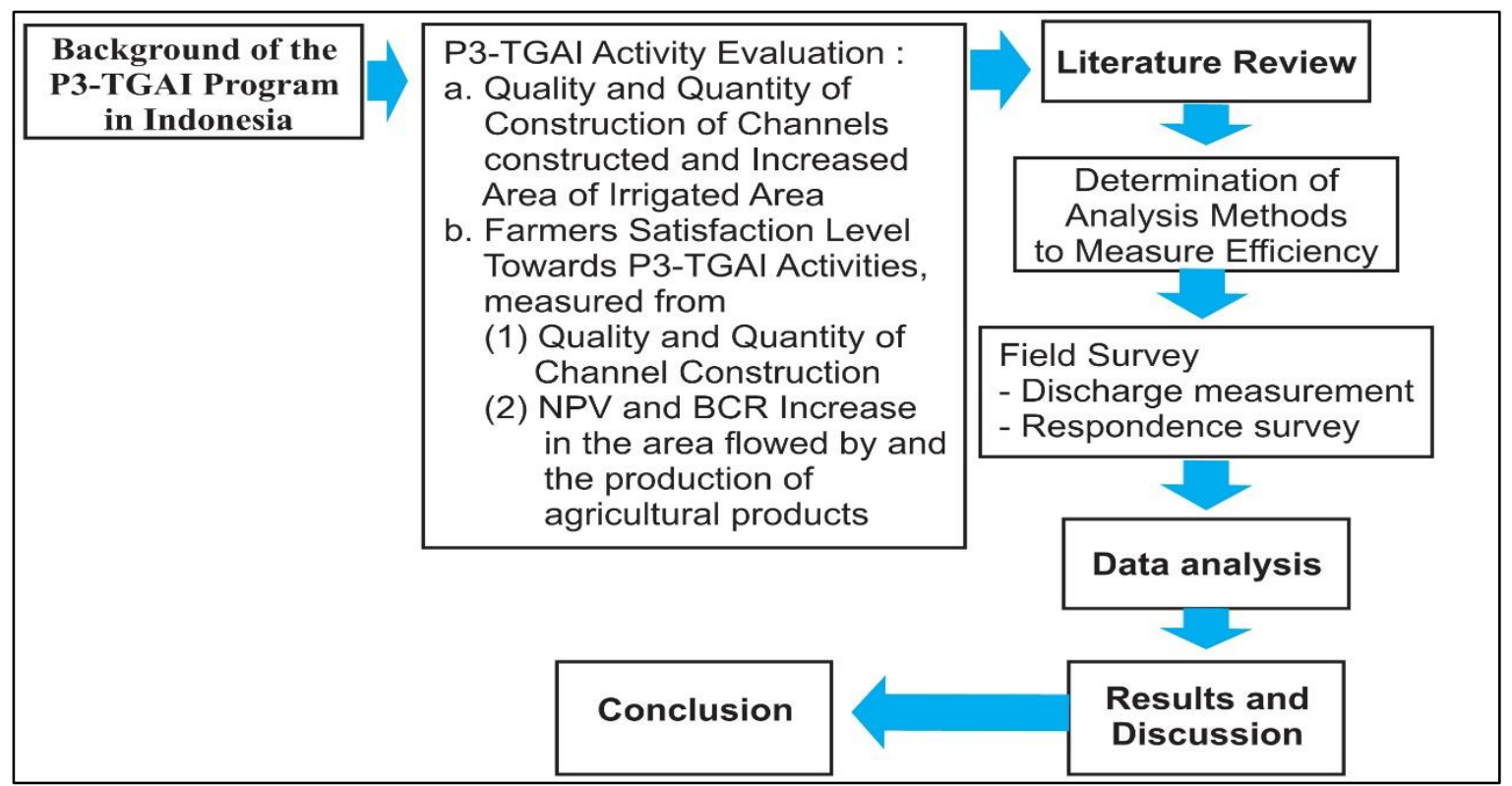

Figure 2 Research flowchart 


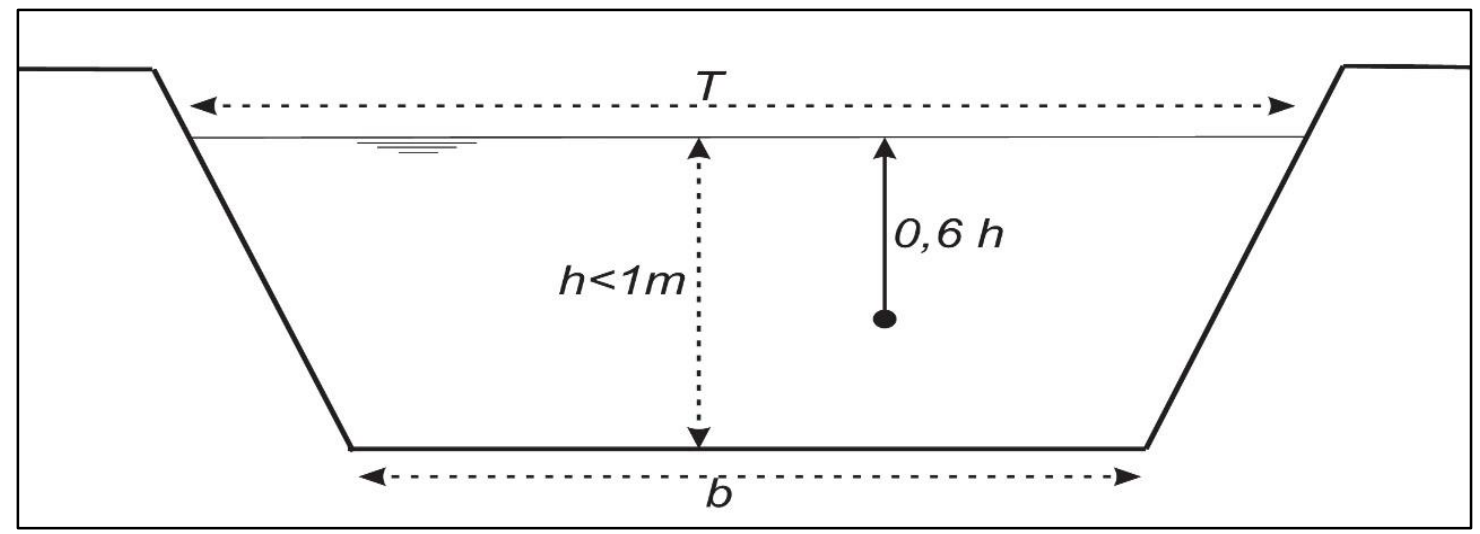

Figure 3 Parameters of flow velocity measurement

Analysis of the water losses in the channel

The quantity of water supply to the rice fields was determined by the water discharged through tertiary channels. It is important to note that the community is responsible for the maintenance of these irrigation channels according to the P3-TGAI program. The amount of water lost $(\Delta Q)$ was calculated by subtracting the outlet discharge $\left(Q_{\text {out }}\right)$ from the inlet discharge $\left(Q_{\text {in }}\right)$ for each type of channel construction as indicated in the following Equation 5. It is also important to note that the efficiency at each channel cross-section was also evaluated [7].

$\Delta Q=Q_{\text {in }}-Q_{\text {out }}$

Irrigation efficiency is based on the assumption that a portion of the water channeled is lost to the canals and rice fields. The water losses calculated for the irrigation operations include those at the tertiary, secondary, and primary levels. The amount in each of these is, however, influenced by the length of the channel, the surface area of the track, the wet circumference of the channel, and the groundwater position [8]. It is important to note that efficient irrigation management focuses on providing suitable irrigation practices for plant cultivation with the water discharged on agricultural lands guaranteeing the proper growth of crops. Moreover, the efficiency of water distribution is determined based on its ability to cover a predetermined percentage of an agricultural area and the calculation of the losses during the distribution. Efficient water use and management are currently a significant concern in many countries of the world, including Indonesia, [9-12]. Meanwhile, the losses of water during distribution are calculated as follows (Equation 6) [13].

$B=\frac{\text { debit inflow-debit out flow }}{\text { debit outflow }} \times 100$.
Where $\mathrm{B}$ is the loss of water during distribution, inflow discharge is the amount of water entering, and outflow discharge is the amount of water coming out. The efficiency is, therefore, calculated using the following equation [8],

$E c=100 \%-B$

Where $E c$ is the efficiency of irrigation water distribution.

Survey on the farmer's level of satisfaction

A survey was conducted to determine the farmers' level of participation in the tertiary network system before and after implementing the P3-TGAI program. This was focused on their satisfaction with the water distribution services and the quality of channel construction implemented by the farmer groups. This analysis was conducted using the Spearman rank correlation to examine the relationship between the factors influencing participation. The data collected were later analyzed qualitatively through reduction, presentation, and conclusion. Moreover, the Likert scale [14] was also applied to obtain the public's perception using the scale which ranges from 1 to 5 to indicate strongly disagree, partly disagree, neutral, agree, and strongly agree consecutively.

The Spearman rank correlation was calculated using the following formula,

$r_{s}=1-\frac{6 \sum d^{2}}{n\left(n^{2}-1\right)}$

Where,

$\mathrm{r}_{\mathrm{s}}=$ Spearman rank correlation value which is the rank correlation coefficient determined based on the size of the relationship between the dependent variable $\mathrm{Y}$ (farmer participation) and the independent variable $\mathrm{X}$ (internal and external factors).

$\mathrm{d}^{2}=$ the difference between $\mathrm{X}$ and $\mathrm{Y}$ ranks.

$\mathrm{n}=$ number of data pairs 
The decision-making rules are as follows:

If the significance value $<\alpha(0.01)$, then $\mathrm{H}_{0}$ is rejected, $\mathrm{H}_{1}$ is accepted and this means there is a relationship between the two variables tested.

If the significance value $>\alpha(0.01)$, then $\mathrm{H}_{0}$ is accepted, $\mathrm{H}_{1}$ is rejected and this means there is no relationship between the two variables tested.

The Net Present Value (NPV) of increasing the area and product of agricultural land based on the changes in the canal structures

The present worth method was applied in this study and is widely used to determine whether a plan has benefits within the analysis period. It is usually used in calculating the difference between the Present Value of the Benefit (PVB) and the Present Value of the Cost (PVC) [15].

This means all the benefits or costs associated with a project are related to their present value using a discount rate and this is presented in the following general equation [16]:

$N P V=\sum_{t=0}^{t} \frac{C_{t}}{(1+\mathrm{i}) \mathrm{t}}-C_{0}$

Where

$\mathrm{NPV}=$ Net present value

$\mathrm{C}_{\mathrm{t}}=$ Net cash inflows (net cash inflow) during period $\mathrm{t}$

$\mathrm{C}_{\mathrm{o}}=$ Total investment costs

$\mathrm{i}=$ Discount interest rate (discount rate)

$\mathrm{t}=$ Duration/economic life of the project

Projects considered to be economically feasible are those with a positive NPV value such that

NPV $>0$ (positive), the project is feasible.

NPV $<0$ (negative), the project is not feasible.

$\mathrm{NPV}=0$, the project benefit is the same as the cost
Benefit-Cost Ratio (BCR) of the channel constructed by the farmer groups

The feasibility of projects developed under P3-TGAI by the farmer groups was evaluated based on the total benefits against costs incurred in the initial year of development using the discount rate of the planned year. The equation for the BCR is, however, presented as follows.

$B C R=\frac{\mathrm{PVB}}{\mathrm{PVC}}$

The value of BCR $<1$ indicates an unfavorable economic investment. The BCR indicators are:

Net BCR> 1, the project is feasible.

Net BCR <1, the project is not feasible.

Net $\mathrm{BCR}=1$, the benefits of the project are proportional to the costs incurred.

\section{Results and discussion}

3.1 NPV and BCR analysis

The change of the tertiary channel construction to concrete is expected to increase the drainage capacity of the channels. The efficiency of each channel is presented in Table 1 and the change of soil to concrete was observed to increase the flow efficiency by $41.11 \%$ as indicated by the increment from the original $53.33 \%$ to $94.44 \%$. The information presented on the tertiary channels in Karangsari and Bedilan villages showed the canal made from natural soil has a lower level of efficiency compared to the loss rate. This is due to a large amount of water wasted in its distribution stream. Moreover, those constructed with bricks were observed to have lesser efficiency than concrete. Therefore, concrete is recommended to ensure the amount of water channelled to the rice fields does not decrease [8].

Table 1 The discharge, water loss, and efficiency in tertiary channels including the soil, brick construction, and concrete lining as well as the increase in the irrigated rice field area at the research location

\begin{tabular}{|c|c|c|c|c|c|c|c|c|c|}
\hline \multirow{2}{*}{\multicolumn{2}{|c|}{$\begin{array}{l}\text { Tertiary channel location } \\
\text { Type of channel material }\end{array}$}} & \multicolumn{4}{|c|}{ Bedilan village } & \multicolumn{4}{|c|}{ Karangsari village } \\
\hline & & \multicolumn{2}{|c|}{ Soil channel } & \multicolumn{2}{|c|}{ Concrete channel } & \multicolumn{2}{|c|}{ Soil channel } & \multicolumn{2}{|c|}{ Brick channel } \\
\hline Parameter & Unit & Inlet & Outlet & Inlet & Outlet & Inlet & Outlet & Inlet & Outlet \\
\hline Debit (Q) & $1 / \mathrm{sec}$. & 0.022 & 0.015 & 0.0285 & 0.027 & 0.022 & 0,0165 & 0.046 & 0.0345 \\
\hline Water lose $(\Delta \mathrm{Q})$ & $1 / \mathrm{sec}$. & 0,007 & & 0,0015 & & 0.0055 & & 0,0015 & \\
\hline Efficiency (Ec) & $\%$ & 53.333 & & 98.47 & & 66.67 & & 66.67 & \\
\hline increased efficiency & $\%$ & 41.107 & & & & 0.00 & & & \\
\hline Increased discharge & 1/sec/ha & 17,25 & & 41.0 & & 19.25 & & 40.3 & \\
\hline Channel Length & $\mathrm{m}$ & 944.9 & & 1,220 & & 446.2 & & 507 & \\
\hline Planted Area & (ha) & 22.2 & & 50,7 & & 23.1 & & 48.3 & \\
\hline $\begin{array}{l}\text { Increase in Planted } \\
\text { Area }\end{array}$ & (ha) & 28,5 & & & & 25.2 & & & \\
\hline
\end{tabular}


The soil tertiary channel in Karangsari village was converted into a brick construction, but the efficiency was observed not to have increased as indicated by the $66.67 \%$ recorded before and after the conversion. Meanwhile, the changes to brick construction and concrete lining caused an increment in rice production due to the increase in the volume of water flow. The standard water requirement for tertiary irrigation networks is $1.2 \mathrm{l} / \mathrm{sec} / \mathrm{ha}$. It was discovered that the discharge in the earth channel is $18.5 \mathrm{l} / \mathrm{sec}$, but the value changed to $27.8 \mathrm{1} / \mathrm{sec}$ after it was rehabilitated using concrete. This further increased in the area of land irrigated by $11.1 \mathrm{Ha}$ as indicated from an increment from 22.2 ha to $33.3 \mathrm{Ha}$ rice planted area after the construction made with concrete lining as indicated in Table 1. The estimation based on the benefits or profit value showed the channel with a concrete structure has $7200 \mathrm{~kg} / \mathrm{ha}$ wet grain production, the total production of unshelled rice with an additional planting area of 11.1 hectares was 79,920 $\mathrm{kg}$, and the price of wet rice per kilo was Rp. 3700 . Meanwhile, the index of rice plants becomes 200 for the rice-secondary-rice cropping pattern after a change in the structure of the canal in one year. Moreover, the increase in the profits obtained by rice production is calculated as follows based on the assumption that the profits obtained by farmers are $40 \%$ of the total agricultural products.

$=\mathrm{La} \times \mathrm{Q} \times \mathrm{P} \times \mathrm{IP} \times 40 \%$

$=11.1 \mathrm{Ha} \times$ Rp. 7,200 tons $/$ ha $\times$ Rp. 3,700 $\times 2 \times 40 \%$

$=$ Rp. 236,563,200, -
Where $L a$ is the land area, $Q$ is the amount of production, $P$ is price, and IP is the planting index.

The benefits obtained with the use of bricks in Karangsari village was the increment in the water discharge to $40.3 \mathrm{l} / \mathrm{sec}$ from $19.25 \mathrm{l} / \mathrm{sec}$ and this further increased the irrigated land area of $25.2 \mathrm{Ha}$ which is from the previous $23.1 \mathrm{Ha}$ to $48.3 \mathrm{Ha}$ as shown in Table 1.

The assessment of this area based on $\mathrm{B} / \mathrm{C}$ showed the price of wet grain per ha was $7200 \mathrm{~kg} / \mathrm{ha}$ and the total production of unshelled rice with an additional planting area of 25.2 hectares was $181,440 \mathrm{~kg}$. Therefore, the increase in rice production per year is calculated as follows

$=\mathrm{La} \times \mathrm{Q} \times \mathrm{P} \times \mathrm{IP} \times 2$ (harvests) $\times 40 \%$

$=25.2 \mathrm{Ha} \times$ Rp. 7,200, - ton $/$ ha $\times 3,700 \times 2 \times 40 \%$

$=$ Rp. 537,062,400, -

The benefits are observed to be due to an increase in water discharge, length of the channel, and the area to be drained. The length of the channel constructed with brick increased to 507 meters while the lightweight concrete is 1,220 meters. Moreover, the use of alternative Ferro cement pairs led to 227 meters increase and this leads to a minimal increase in the volume of brick and light concrete construction when applied as indicated in Table 2.

Table 2 Recap of the results of the addition of gain flow area and B/C in Bedilan and Karangsari villages

\begin{tabular}{|c|c|c|c|c|c|c|}
\hline $\begin{array}{l}\text { Tertiary Channel } \\
\text { location }\end{array}$ & \multicolumn{3}{|c|}{ Bedilan village (light concrete) } & \multicolumn{3}{|c|}{ Karangsari village (brick construction) } \\
\hline \multirow{2}{*}{$\begin{array}{l}\text { Benefit value } \\
\text { Parameter }\end{array}$} & Channel length & \multicolumn{2}{|c|}{ Production (Kg) } & Channel length & \multicolumn{2}{|c|}{ Production (Kg) } \\
\hline & Value & Grain & rice & Value & Grain & Rice \\
\hline & (m) & $(\mathrm{kg})$ & (kg) & (m) & $(\mathbf{K g})$ & (Kg) \\
\hline Benefit value & 944.9 & 79,920 & 39,960 & 446.2 & 181,440 & 90,720 \\
\hline Cost (Rp.) & $195,000,000$ & - & & $195,000,000$ & - & \\
\hline Price per Kg (Rp) & - & $3,700,-$ & $8,400,-$ & & 3,700 & 8,400 \\
\hline Benefit per year (Rp) & - & $236,563,200$ & $268,531,200$ & & $537,062,400$ & $609,638,400$ \\
\hline NPV (10 y ears) $(\mathrm{Rp})$ & - & $1,602,745,000$ & & - & $3,742,340,000$ & \\
\hline $\mathrm{B} / \mathrm{C}$ & 53.333 & 6.79 & & 66.67 & 14.53 & \\
\hline Conclusion & $6.79>0$, well & & & 14.530, well & & \\
\hline
\end{tabular}

3.2 Analysis of the increasing benefits for farmers

The analysis of data obtained from 115 respondents showed the Spearman Coefficient (rs) was $0.841^{* *}$, the $\mathrm{H}_{0}: \rho=0$ indicates the absence of correlation, and H1: $\rho \neq 0$ indicates a correlation between the implementation and impact of the P3-TGAI program. The level of education of the respondents includes primary school with $27.83 \%$, junior high school with 581
$20 \%$, senior high school with $29.57 \%$, bachelor degree with $4.35 \%$ while those without education are $18.26 \%$. It is important to note that the primary data was obtained using questionnaires and depth interviews.

The results showed the level of farmer satisfaction with the physical channel constructed with bricks was $0.815^{* *}$ while the concrete lining was $0.864^{* *}$. 
Moreover, the concrete lining construction was discovered to have a better confidence level of 0.932 ** due to its better quality as observed with the service age and a more significant water discharge to be used in processing the fields.

\section{Conclusion and future work}

The results showed a higher increase in the flow rate of irrigation and rice production for channels constructed with concrete lining in comparison with bricks and soil. Moreover, the level of farmer confidence in the P3-TGAI activity was found to be $0.841 * *$ with the brick construction dis covered to have $0.815 * *$ while the concrete lining had $0.864 * *$. The level of satisfaction in the building quality was also found to be $0.932 * *$. The level of satisfaction of the farming community with the use of concrete lining in the P3-TGAI program can be improved through the utilization of ferrous cement in the repair of the tertiary irrigation channels. This is due to its much cheaper cost of construction with minimal loss when compared with the use of concrete lining.

\section{Acknowledgment}

The authors are grateful to the Department of Civil Engineering and Planning Study Program, Faculty of Engineering. Sriwiiava University for the knowledge acquired between 2019-2021.

\section{Conflicts of interest}

The authors have no conflicts of interest to declare.

\section{References}

[1] UNICEF. The state of food security and nutrition in the world 2020. Transforming Food Systems for Affordable Healthy Diets. 2020.

[2] https://www.cnnindonesia.com/nasional/20200624144 130-20-516938/Kemenhan-dorong-food-estatekalteng-lsm-sebut-janji-kosong. Accessed 20 April 2021.

[3] Mitra BK, Sahin S, Markandy a A, Ngoc BP. Improving irrigation water use efficiency holds the key to tackling water scarcity in South Asia: technical potential and financing options. IGES-Policy Brief. 2017; 39:1-12.

[4] KP PEOPLE. Republic of Indonesia. The 1945 Constitution of the Republic of Indonesia in One Text. 2009.

[5] http://sda.pu.go.id/produk/view_produk/Laporan_Kine rja_Ditjen_SDA_Tahun_2019. Accessed 20 April 2021.

[6] People KP. Technical guidance for water use development in the context of PTGA instructor technical training. Tahun. 2019.

[7] Putranto DD, Sarino AY, Yudha AK. Optimizing the irrigation water needs of lebak semendawai swamp in increasing agricultural production. International
Journal of Environment, Agriculture and Biotechnology. 2020; 5(1):109-19.

[8] Han X, Wang X, Zhu Y, Huang J, Yang L, Chang Z, et al. An experimental study on concrete and geomembrane lining effects on canal seepage in arid agricultural areas. Water. 2020; 12(9):1-21.

[9] Barkhordari S, Shahadany SH, Taghvaeian S, Firoozfar AR, Maestre JM. Reducing losses in earthen agricultural water convey ance and distribution systems by employing automatic control systems. Computers and Electronics in Agriculture. 2020.

[10] Hatamkhani A, Moridi A. Optimal development of agricultural sectors in the basin based on economic efficiency and social equality. Water Resources Management. 2021; 35(3):917-32.

[11] Koech R, Langat P. Improving irrigation water use efficiency: a review of advances, challenges and opportunities in the Australian context. Water. 2018; 10(12):1-17.

[12] Tawfik AM. Design of channel section for minimum water loss using lagrange optimization and artificial neural networks. Ain Shams Engineering Journal. 2021; 12(1):415-22.

[13] Mohammadi A, Rizi AP, Abbasi N. Field measurement and analysis of water losses at the main and tertiary levels of irrigation canals: varamin irrigation scheme, Iran. Global Ecology and Conservation. 2019; 18:1-10.

[14] Lobo M, Guntur RD. Spearman's rank correlation analy sis on public perception toward health partnership projects between Indonesia and Australia in East Nusa tenggara province. In journal of physics: conference series 2018 (pp. 1-6). IOP Publishing.

[15] Krupnik T, Jenkins MW, Mooney S, Bett EK. Net present value analysis to assess the economic consequences of changing farming sy stems in the upper catchment of the river Njoro watershed. In proceedings of the tenth biennial scientific conference \& agricultural forum, Keny a agricultural research institute 2006 (pp. 12-7).

[16] Senkondo EM, Msangi AS, Xavery P, Lazaro EA, Hatibu N. Profitability of rainwater harvesting for agricultural production in selected semi-arid areas of Tanzania. Journal of Applied Irrigation Science. 2004; 39(1):65-81.

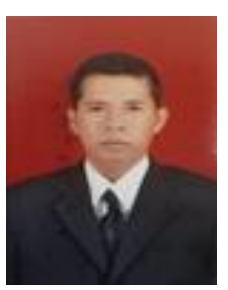

Iskandar Pani was born in Gumawang, OKU Timur District South Sumatra in September 25, 1972. $\mathrm{He}$ is a Postgraduate student of the Water Resources Management, Civil Engineering Study Program, Faculty of Engineering, Sriwijay a University and works at the Balai Sungai Wilay ah VI, Ministry of Public Works of the Republic of Indonesia. As the Head of the East OKU Irrigation Unit, he has conducted several maintenance activities for the tertiary irrigation network in the Komering Irrigation System, South Sumatra Email: Iskandar_pani72@yahoo.com 


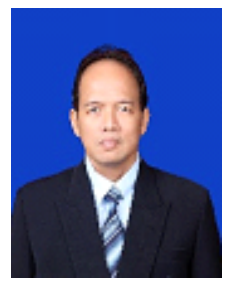

Dinar Dwi Anugerah Putranto wasbom in Yogyakarta on June 30, 1960. He is an educational background in Geomatics, Remote Sensing, and GIS. $\mathrm{He}$ is a Professor of Civil Engineering at the Faculty of Engineering, Sriwijaya University with focus on the use of GIS techniques for spatial analy sis in erosion sedimentation and flood modeling. He has professional experience in Spatial Planning at the provincial, district, and city levels participated effectively in the one map policy implemented at the regional level of South Sumatra.

Email: dwianugerah@yahoo.co.id

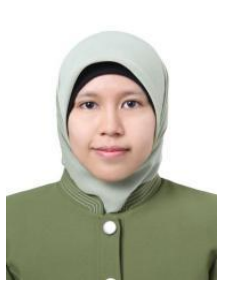

Putri Kusuma Wardhani was born in Palembang, June 11, 1988. She has her undergraduate education in Civil Engineering while her Master's and Doctorate Degree were completed in the Environment field at Okayama University, Japan. She has several environmental research experiences published in national and international journals.

Email: puterikusuma@gmail.com 